\title{
Benson's Relaxation Therapy and Sleep Quality among Elderly at a Social Institution in Inakaka, Indonesia
}

\author{
Nur Baharia Marasabessy ${ }^{1}$, Lucky Herawati ${ }^{2 *}$, Irhamdi Achmad ${ }^{1}$
}

${ }^{1}$ Maluku Health Polytechnic of Ministry of Health, Ambon, Indonesia

${ }^{2}$ Yogyakarta Health Polytechnic of Ministry of Health, Special Region of Yogyakarta, Indonesia

\begin{abstract}
Serious sleep disturbances among elderlies include attention or memory disorders, depression and often fall. A quasi experimental study design with pre-post test with control group was performed to determine effect of Benson's relaxation therapy on sleep quality among the elderly, and influences of sex, age and disease suffered differences. Of a total of 46 elderlies from a Social Institute in Ambon, 29 were taken for the treatment group and 19 for the control group. The treatment group was interfered with Benson's breathing relaxation for 14 days. Sleep quality was measured using Pittsburg sleep quality index form. Data were analyzed using independent t-test and multivariate of variance with signifinat level 0.05 . This study found that Benson's relaxation therapy was able to improve significantly the elderly sleep quality ( $p$-value $=0.046)$, and no significant difference between sex, age and disease suffered in elderly sleep quality ( $p$-value $>0.05)$. The Benson's relaxation therapy was able to improve the elderly sleep quality especially in Inakaka Social Institution.
\end{abstract}

Keywords: Benson's relaxation theraphy, elderly, sleep quality

\section{Introduction}

Elderly is a natural process determined by God, a person will experience the process of grwing old in which he or she gets a physical, mental and social slowdown gradually. The World Health Organization (WHO) estimates that by 2025 the number of elderly people worldwide will reach 1.2 billion people which will continue to grow to 2 billion by 2050 . WHO also estimates that $75 \%$ of the world's elderly population by 2025 is in some developing countries. In Indonesia, the results of the 2010 population census show that Indonesia is among the top five countries with the largest population of elderly in the world. In 2010, the number of elderly in Indonesia reached 18.1 million people. While, National Census data from the Statistics Indonesia shows the elderly in Indonesia at $7.56 \%$ of the total population of Indonesia. Most of the elderly in Indonesia are female. ${ }^{1}$ The large number of elderly people in Indonesia can be interpreted as the success of human development in relation to the indicators of increasing life expectancy. On the other hand, that number presents a challenge on the number of dependencies, which in turn correlates with the economic burden borne by the productive age population. Elderly prob-

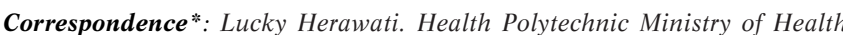
Yogyakarta, Tatabumi Street number 3, Banyuraden, Gamping, Sleman, 55203, E-mail: lucky08081953@gmail.com, Phone: +6281392414153 lems are not only limited to productivity but also related to other things such as education and health. One of the health problems most often complained of by the elderly is sleep disorder.

Sleep is a basic need for every human being. Sleep is a change in the state of consciousness that occurs during a certain period marked by the provision of time for improvement and healing of the body system by obtaining adequate sleep. With adequate rest and sleep, the body can function optimally. This is based on the belief that sleep can restore or rest physical after a day of activity, reduce stress and anxiety, and can improve the ability and concentration when about to perform daily activities. Inadequate sleep requirement will cause sleep disturbance. Sleep is stated as vital role in central nervous system restoration, memory consolidation and affect regulation. ${ }^{2}$

Insomnia is the most common sleep disorder. ${ }^{3}$ Every year, it is estimated that about $20 \%-50 \%$ of adults report a sleep disorder and about $17 \%$ have serious sleep disorder. The prevalence of sleep disorder in elderly is quite high at around $67 \%$. More than half elderly patients in primary care physician and psychiatric complaint about their poor sleep quality. It is a common 
health problem in elderly people. ${ }^{4}$ However, only one in eight cases stated that the sleep disorder had been diagnosed by a doctor. Impacts that occur when a person is unable to meet his or her sleeping needs are personality and behaviour changes, such as aggressive, withdrawal or depression, increased sense of distraction, perceptual disorder, auditory hallucinations or vision, confusion and disorientation of place and time, decreased coordination and speech unclear, irritable and not relaxed. Poor sleep in older adult may result in increasing risk of falls, lower quality of life, risk of nursing home placement and mortality. ${ }^{5}$ Insomnia is the most common sleep difficulty reported in elderly adults especially elderly woman. 2,6

Many factors affect the quality and quantity of sleep, including diseases, environment, fatigue, lifestyle, emotional stress, stimulant and alcohol, diet, smoking, medication and motivation. First line treatment of elderly sleep disturbance is non-pharmacological. ${ }^{8}$ One of the pharmacological intervention is relaxation method. It can happen because the relaxation contained elements of self-calm. One of the relaxation techniques that can be used is Benson's relaxation. Benson's relaxation is a procedure to help individuals deal with stressful situations and effort to relieve stress. There are four kinds of relaxation according to Benson that is muscle relaxation (progressive muscle relaxation), diaphragmatic breathing, attention focus on exercises, and behaviour relaxation training. Benson's relaxation is the development of a respiratory relaxation response method involving patient confidence factors, which can create an internal environment; for further relaxation Benson can help patients achieve health and welfare conditions higher. ${ }^{9}$ Excess relaxation technique training compared to other exercises is relaxation exercises easier to do even under any circumstances and have no side effects. More than 3,000 studies show the beneficial effects of relaxation on health and wellbeing. ${ }^{10}$ In addition, relaxation techniques more easily implemented by patients, can reduce medical costs, and can be used to prevent the occurrence of stress. Another thing to consider is the long-term administration of chemical medicines can cause side effects that can endanger the wearer as a kidney disorder, while relaxation is not a harmful side effect.

In Ambon, Maluku, there are elderly inhabitants in social institution, one of them is Tresna Werdha Inakaka Social Institution inhabited by 46 elderly people. Based on the information from the social institution management, the elderly in the social home were experiencing sleep disorder. Sleep disorder is known as a significant cause of morbidity. There are some serious effects of sleep disorders in the elderly, such as excessive daytime drowsiness, attention or memory disorders, depressed mood, frequent falls, improper use of hypnotics and decreased quality of life. This study aimed to know whether there was influence of Benson's relaxation therapy on sleep quality elderly in the social home, also to know whether there were any difference in sex, age, and types of disease suffered by elderly in quality of sleep.

\section{Method}

This study was a quasi-experimental study with nonequivalent pretest and posttest with control group design conducted on the study subjects of all residents of the Tresna Werdha Inakaka Social Institution Ambon City, Maluku Province, consisting of 46 people. The subjects of the study were divided into 2 groups based on their occupancy group (non-randomized), e.g., 29 elderly residents of building "A" as an experimental group and 19 elderly residents of building "B" as a control group. The study was conducted in July - August 2016. The subjects were trained first by researchers assisted by four students of Diploma III in Nursing for two days.

Intervention in the form of Benson's relaxation therapy performed 10 - 20 minutes every night (before bed) for 14 days by subjects and supervised by researchers. The steps taken were (a) choosing the spiritual phrase to be used, ask the respondent to close his/her eyes, ask the respondent to relax his muscles by using progressive relaxation e.g., ask the patient to hold the second (repeated $2 \mathrm{x}$ ); (b) bending both wrists toward the arm, so that the back and lower arm muscles tighten, release slowly (done as much as $2 \mathrm{x}$ ); (c) clenching both hands, bring both fists to the shoulder so that the biceps muscles become tense, lower the hands slowly (done as much as $2 \mathrm{x}$ ); (d) lifting both shoulders as high as touching both ears; (e) wrinkling forehead and eyebrows until the skin feels wrinkled while closing the eyes so hard that it can feel the tension around the eyes and muscles that control eye movement, release slowly (repeated 2x); (f) clenching the jaw followed by teeth biting so that there is tension around the jaw muscles; pouting the lips as hard as it will feel the tension around the mouth; pressing the head into the cushion so that it can feel the tension in the front of the neck and upper back, relax (done as much as $2 \mathrm{x}$ ); (g) advancing the head forward, sink the chin to the chest, so it can feel the tension in the back of the neck area, relax, repeat twice; puffing out the chest, holding the tense condition on the back muscles for 10 seconds, relax, and repeat twice; straightening both the legs, so that the thigh muscles become tense, hold 10 seconds, release, repeat twice; followed by locking the knee in such a way that the tension moves on the calf muscle, hold position for 10 seconds, release (done as much as $2 \mathrm{x}$ ); (h) breathing naturally begins by reciting a spiritual phrase that is read repeatedly and solemnly, if there is a disturbing thought, go back to focus the mind. The activity was done for 10 
to 20 minutes. Participants were requested not to stand up at once, but were required to sit down and rest, open their minds, and then re-engage.

The result of measured intervention was the sleep quality expressed by the value of the global Pittsburg Sleep Quality Index (global PSQI). Sleep quality is one's satisfaction with sleep over the duration of sleep, the time it takes to fall asleep, the frequency of awakening and subjective aspects such as depth and sleep deprivation. It was measured by interview using the "Pittsburg" sleep quality index (PSQI) form, ${ }^{8}$ which includes seven components of sleep quality values, such as sleep onset latent, sleep duration, sleep sufficient, sleep disorder, sleep medication, daytime disfunction, subjective sleep quality. Each component is rated between $1-3$, so the value of sleep quality was 21 of a maximum. If the global PSQI value $<5$, including sleep quality "good" and if the global value of $\mathrm{PSQI} \geq 5$, including sleep quality "bad". ${ }^{12,13}$ Measurements of sleep quality values (preliminary global value of PSQI) were performed the day before the intervention and final measurement (posttest) was performed after 14 days of treatment. It was collected with the assistance of four students of Diploma III in Nursing in the morning. The data obtained were tested with independent $\mathrm{t}$-test and multivariate analysis of variance test with level of significant 0.05 , which was first tested of data normality (Shapiro-Wilk analyses) because the number of sample was less than 50 subjects. ${ }^{14-16}$ This study received Ethical approval from Health Research Ethics Commission of Surabaya Health Polytechnic of Ministry of Health, Number: 050/S/Kep/VI/2017, dated on June 13, 2017.

\section{Results}

Most respondents were females $(65.21 \%)$, aged 60 74 years old $(54.34 \%)$ and had hypertension $(30.43 \%)$ and uric acid (26.08\%). After conducting independent ttest and multivariate test to the respondent's characteris- tic data, it was known that "there is no significant difference" in characteristics of respondents in two experimental groups and control group ( $\mathrm{p}$-value $>0.05$ ). More can be seen in Table 1.

The sleep quality of respondents is expressed in the global value PSQI. The decrease of global PSQI score (pre and post- test) was declared to be normal distribution due to $p$-value $=0.664(p$-value $>0.05)$. The average value of sleep quality in male respondents was 6.44 and the value of female respondents is 7.63. Although both values were different, they both included "poor" sleep quality because of the global PSQI value $>5$. In addition, after the independent statistical $t$-test showed "no significant difference" between the two values ( $p$-value $=0.282$ or $>0.05$ ). Thus, sleep quality in male and female respondents at the beginning of treatment was the same.

Similarly, the age characteristics of the 56-74-years age group and the age group of $\geq 75$ years, both had poor sleep quality, because the global PSQI score on the respondents of the age group 56 - 74 years was 6.88 and the age group $\geq 75$ years was 7.62 . Although the old age group seemed bigger than the previous age group, but both values still showed the quality of sleep "bad". In addition, after the independent t-test of both values, the results showed no significant difference between the two age groups in terms of sleep quality ( $\mathrm{p}$-value $=0.488$ or p-value $>0.05)$. In other words, the prior treatment of sleep quality in different respondents the age group was the same.

The respondents who had the disease and did not have the disease disorder, both had poor sleep quality because all of them had global value of PSQI $\geq 5$. Respondents who got acute respiratory infections (ARI) disease had the highest global PSQI score, at 8.00. Respondents with hypertensive disorders and uric acid also had relatively high global PSQI values as well, e.g., 7.86 and 7.83. This means that respondents with ARI, hypertension and uric acid have the worst quality of sleep

Table 1. Characteristics of the Study Subjects at Tresna Werdha Inakaka Social Institution in Ambon, 2016

\begin{tabular}{|c|c|c|c|c|c|c|c|c|}
\hline \multirow{2}{*}{ Variable } & \multirow{2}{*}{ Category } & \multicolumn{2}{|c|}{ Experimental Group $(n=27)$} & \multicolumn{2}{|c|}{ Control Group $(n=19)$} & \multicolumn{2}{|c|}{ Total $(n=46)$} & \multirow{2}{*}{ p-value } \\
\hline & & $\mathbf{F}$ & $\%$ & $\mathbf{F}$ & $\%$ & $\mathbf{F}$ & $\%$ & \\
\hline \multirow[t]{2}{*}{ Sex } & Male & 7 & 25.9 & 9 & 47.4 & 16 & 34.78 & $0.139 *)^{\mathrm{a}}$ \\
\hline & Female & 20 & 74.1 & 10 & 52.6 & 30 & 65.21 & \\
\hline \multirow[t]{2}{*}{ Age } & $56-74$ years & 12 & 44.4 & 13 & 68.4 & 25 & 54.34 & $\left.0.113^{*}\right)^{\mathrm{a}}$ \\
\hline & $\geq 75$ years & 15 & 55.6 & 6 & 31.6 & 21 & 45.65 & \\
\hline \multirow[t]{9}{*}{ Illness } & Hypertension & 8 & 29.6 & 6 & 31.6 & 14 & 30.43 & $\left.0.855^{*}\right)^{b}$ \\
\hline & Diabetes mellitus & 1 & 3.7 & 2 & 10.5 & 3 & 6.52 & \\
\hline & Uric acid & 8 & 29.6 & 4 & 21.1 & 12 & 26.08 & \\
\hline & Ear disorder & 4 & 14.8 & 2 & 10.5 & 6 & 13.04 & \\
\hline & Cataract & 3 & 11.1 & 2 & 10.5 & 5 & 10.86 & \\
\hline & Acute respiratory infections & 0 & 0 & 1 & 5.3 & 1 & 2.17 & \\
\hline & Hypertension and post-stroke & 1 & 3.7 & 1 & 5.3 & 2 & 4.34 & \\
\hline & Hernia & 0 & 0 & 1 & 5.3 & 1 & 2.17 & \\
\hline & No disorder & 2 & 7.4 & 0 & 0 & 2 & 4.34 & \\
\hline
\end{tabular}

Notes: $\mathrm{a}=$ Independent $\mathrm{t}$-test, $\mathrm{b}=$ Multivariate test, ${ }^{*}$ ) level of significant 0.05 
compared to respondents with other diseases. However, having tested with multivariate test showed that there was no significant difference in the value of global PSQI on different respondent types of illness ( $p$-value $=0.898$ or p-value >0.05). More can be seen in Table 2 .

At the time of initial measurement, it was found that there were 10 people or $37 \%$ of respondents in the experimental group whose sleep quality was "good" (total PSQI score < 5) and after Benson's relaxation interventions for 14 days increased to 18 persons or $66.7 \%$. The same thing happened in the control group. However the increase in the number of elderly in the group of "good" sleep quality is very little e.g., only one person. More can be seen in Table 3 .

To determine whether there was a significant decrease in global PSQI values before and after treatment in the experimental and control group, testing was done on the global value of PSQI and its components with multivariate of variance test. Overall, multivariate of variance test results showed there was a significant difference in the value of global PSQI between the experimental and control groups with $\mathrm{p}$-value $=0.005$ or $\mathrm{p}$-value $<0.05$. In other words, there was a significant difference in the quality of elderly sleep between the experimental group and the control group. The test results on each subject (global PSQI value and its components) can be seen in Table 4.

Table 4 shows that the different meanings of the global value of PSQI between the experimental and control groups were supported by 2 (two) components, namely sleep latency and sleep duration with p-values $=0.023$ and 0.010 .

\section{Discussion}

At the beginning of the measurement, there were 17 people with poor sleep quality $(63 \%)$. This condition is in line to study by Mohsen Adib, ${ }^{4}$ showing that, at the baseline, sleep quality in both group (intervention and control groups) was low. The percentage of respondents with poor sleep quality is still lower than the percentage of elderly people with insomnia at Tresna Werdha Ganti Mabaji Social Institution in Gowa District, which amounted to $82.29 \%$. Study at King Abdulaziz University Hospital Intensive Care Unit (ICU) demonstrated that there were 26 ICU patients. All the participants $(100 \%)$ in that place had poor quality sleep and the factors affecting sleep were varied. ${ }^{17}$ After treatment, Benson's relaxation therapy for 14 days, there was a decrease in the number of elderly people with poor sleep quality, from 17 people $(63 \%)$ to 9 people $(33.33 \%)$.

Table 2. Sleep Quality Based on Respondent's Characteristics

\begin{tabular}{|c|c|c|c|c|c|}
\hline \multirow{2}{*}{ Variable } & \multirow{2}{*}{ Category } & \multicolumn{4}{|c|}{ Sleep Quality Value (Global PSQI) } \\
\hline & & Total & Mean \pm SD & p-value & p-value ${ }^{b}$ \\
\hline \multirow[t]{2}{*}{ Sex } & Male & 16 & $6.44 \pm 3.22$ & $0.282 *)$ & \\
\hline & Female & 30 & $7.63 \pm 3.70$ & & \\
\hline \multirow[t]{2}{*}{ Age } & 56-74 years & 25 & $6.88 \pm 3.60$ & $\left.0.488^{*}\right)$ & \\
\hline & $\geq 75$ years & 21 & $7.62 \pm 3.52$ & & \\
\hline \multirow[t]{9}{*}{ Illness } & Hypertension & 14 & $7.86 \pm 4.18$ & & $0.898 *)$ \\
\hline & Diabetes mellitus & 3 & $7.00 \pm 2.64$ & & \\
\hline & Uric acid & 12 & $7.83 \pm 3.53$ & & \\
\hline & Ear disorder & 6 & $5.17 \pm 2.56$ & & \\
\hline & Cataract & 5 & $6.80 \pm 3.42$ & & \\
\hline & Acute respiratory infections & 1 & $8.00 \pm 0.00$ & & \\
\hline & Hypertension and post-stroke & 2 & $5.50 \pm 0.70$ & & \\
\hline & Hernia & 1 & $6.00 \pm 0.00$ & & \\
\hline & No disorder & 2 & $8.50 \pm 7.77$ & & \\
\hline
\end{tabular}

Notes: PSQI: Pittsburg Sleep Quality Index, a = Independent t-test, b = Manova, *) level of significant 0.05

Table 3. Quality of Elderly Sleep in Experimental Group and Control Group

\begin{tabular}{|c|c|c|c|c|c|c|c|c|}
\hline \multirow{3}{*}{ Group } & \multicolumn{4}{|c|}{ Pretest } & \multicolumn{4}{|c|}{ Posttest } \\
\hline & \multicolumn{2}{|c|}{ Good } & \multicolumn{2}{|c|}{ Poor } & \multicolumn{2}{|c|}{ Good } & \multicolumn{2}{|c|}{ Poor } \\
\hline & $\mathbf{F}$ & $\%$ & $\mathbf{F}$ & $\%$ & $\mathbf{F}$ & $\%$ & $\mathbf{F}$ & $\%$ \\
\hline Experimental $(n=27)$ & 10 & 37 & 17 & 63 & 18 & 66.7 & 9 & 33.3 \\
\hline Control $(n=19)$ & 7 & 35.8 & 12 & 63.2 & 8 & 42.1 & 11 & 57.9 \\
\hline
\end{tabular}

Notes:

Global PSQI score 5 = sleep quality is poor

Global PSQI score $<5$ = sleep quality is good 
Table 4. Pittsburg Sleep Quality Index Global Value and its Components (the Result of the Multivariate of Variance Test)

\begin{tabular}{|c|c|c|c|c|}
\hline \multirow{2}{*}{ Variable } & \multirow{2}{*}{ Group } & \multirow{2}{*}{$\frac{\text { Pretest }}{\text { Mean (SD) }}$} & Posttest & \multirow{2}{*}{$\begin{array}{l}\text { Difference } \\
\text { Mean (SD) }\end{array}$} \\
\hline & & & Mean (SD) & \\
\hline \multirow[t]{3}{*}{ Total PSQI } & Experimental & $7.56(3.68)$ & $4.85(2.42)$ & $2.70(3.86)$ \\
\hline & Control & $6.74(3.39)$ & $6.68(3.90)$ & $0.05(4.88)$ \\
\hline & $\mathrm{p}$-value ${ }^{\mathrm{a}}$ & 0.448 & 0.056 & $0.046 *)$ \\
\hline \multirow[t]{3}{*}{ Sleep latency } & Experimental & $1.33(0.73)$ & $0.78(0.50)$ & $0.56(0.97)$ \\
\hline & Control & $0.89(0.93)$ & $1.21(1.10)$ & $0.32(1.52)$ \\
\hline & p-value ${ }^{a}$ & 0.082 & 0.066 & $0.023 *)$ \\
\hline \multirow[t]{3}{*}{ Sleep duration } & Experimental & $1.93(0.95)$ & $1.11(0.69)$ & $0.81(0,78)$ \\
\hline & Control & $1.58(0,83)$ & $1.47(1.07)$ & $0.11(0.99)$ \\
\hline & p-value ${ }^{a}$ & 0.210 & 0.172 & $0.010 *)$ \\
\hline \multirow[t]{3}{*}{ Sleep sufficient } & Experimental & $1.26(1.13)$ & $0.81(0.83)$ & $0.44(1.34)$ \\
\hline & Control & $1.26(0.99)$ & $0.95(0.84)$ & $0.32(1.06)$ \\
\hline & p-value ${ }^{a}$ & 0.990 & 0.601 & 0.729 \\
\hline \multirow[t]{3}{*}{ Sleep disorder } & Experimental & $1.15(1.23)$ & $0.44(0.75)$ & $0.70(1.43)$ \\
\hline & Control & $0.89(1.15)$ & $0.63(0.68)$ & $0.26(1.32)$ \\
\hline & p-value ${ }^{a}$ & 0.484 & 0.393 & 0.296 \\
\hline \multirow[t]{3}{*}{ Sleep medication } & Experimental & $1.44(0.64)$ & $1.26(0.52)$ & $0.19(0.83)$ \\
\hline & Control & $1.42(0.50)$ & $1.26(0.45)$ & $0.16(0.60)$ \\
\hline & p-value ${ }^{a}$ & 0.895 & 0.979 & 0.904 \\
\hline \multirow[t]{3}{*}{ Daytime disfuction } & Experimental & $0.19(0.48)$ & $0.11(0.42)$ & $0.07(0.67)$ \\
\hline & Control & $0.21(0.71)$ & $0.21(0.71)$ & $0.00(1.05)$ \\
\hline & $\mathrm{p}$-value ${ }^{\mathrm{a}}$ & 0.886 & 0.557 & 0.773 \\
\hline \multirow[t]{3}{*}{ Subjective sleep quality } & Experimental & $0.26(0.52)$ & $0.33(0.55)$ & $-0.07(0.73)$ \\
\hline & Control & $0.47(0.51)$ & $0.95(0.62)$ & $-0.47(0.90)$ \\
\hline & p-value & 0.176 & 0.001 & 0.105 \\
\hline
\end{tabular}

Notes: Pittsburg Sleep Quality Index, p-value ${ }^{\mathrm{a}}=$ Manova test; ${ }^{*}$ ) level of significance 0.05

When compared with the results of epidemiologic surveys on elderly living at home or in nursing homes, which was quoted by Prayitno, ${ }^{19}$ that the percentage of elderly people with poor sleep quality in Ambon is still in the range of the results of epidemiologic surveys at $15-75 \%$. So, the number of people with poor sleep in this research before or after treatment was still higher than result of previous survey.

The decreasing value of sleep quality was significant both the experimental group and the control group, supported by significant differences in the component values of sleep latency and sleep duration. This result is in line with the report of the journalists. They reported that there were 75 elderly suffering from sleep disorder in Iran. There were randomly assigned to either intervention $(n=38)$ or control $(n=38)$. The intervention group received Benson's relaxation technique twice a day for 20 minutes through 4 weeks. The t-test analysed showed that there was a significant improvement in intervention group in quality of sleep. ${ }^{18}$ The other side, the Ambon's result contrast to the results of Rambod's study, ${ }^{12}$ on haemodialysis patients in Iran in 2013. The study did not show significant differences between the experimental group and the control group including its components. The difference in the results of the study lies in the form of the intervention and the characteristics of the subject. Rambod's study, ${ }^{12}$ used audiotape of Benson's relaxation technique, while the present study provides guided intervention for patients to have Benson's relaxation. In addition, Rambod's study used patient subjects in two haemodialysis units, while the present study used the elderly at two social homes.

The present study in Ambon, can improve the sleep quality of the elderly (decreased global value of PSQI) after Benson's relaxation therapy. This is because this technique stimulates the activity of the parasympathetic nervous system consciously, and strains a group of muscles and releases tension in the muscle group. This relaxation technique exercise will cause the release of chemical bonds, especially actin and myosin from the cross bridge in the muscle, so that the muscles relax. ${ }^{20}$ After the muscles relax, other components of the natural relaxation response will follow. Relaxing muscles require less oxygen, so that the breathing pattern slows down and deep, the heart does not need to pump too fast to carry oxygen to the tight muscles. Heart rate and blood pressure decrease. Blood flow to the stomach and digestive system becomes normal. The stomach becomes calm, the hands and feet are warm, so that the series of body adaptations occur naturally and then the body becomes relaxed calmer and fresh. Gardiner P, et al., ${ }^{10}$ said how relaxation technique works. It refers to changes that occur in the body when it is in a deep state of relaxation. These changes include decreasing blood pressure, heart rate, 
muscle tension, and rate of breathing as well as feeling of being calm and in control.

Benson's relaxation is a very simple relaxation technique which is a combination of relaxation with the patient's religious beliefs. When a person has reached the right stage of relaxation, the body can experience several changes including increased peripheral blood flow, increased immune cell activity, reduced body oxygen consumption, elimination of carbon dioxide, decreased blood lactate level, decreased heart rate, reduced tension skeletal muscle, decreases the level of epinephrine, and stimulates the production of slow alpha waves in the brain, as well as the release of neurotransmitters which act as sedatives. In addition, relaxation exercises can provide a gentle massage to various glands in the body, reduce the production of cortisol in the blood, restore sufficient expenditure of hormones to provide emotional balance and peace of mind. ${ }^{21}$ These conditions can cause a relaxed state, so that it can improve sleep quality. Benson's relaxation is an alternative effort in addition to the use of sleep-inducing medicines, stated that relaxation therapy clinically has the same effect as the use of sleep-inducing medicines to treat insomnia. Although both way, namely the use of sleep-triggering medicines and Benson's relaxation therapy have the same effect on sleep quality, however, in the elderly, it is recommended to minimize the pharmacological method due to side effects that will ultimately endanger the elderly, so that nonpharmacological methods are more recommended. One of the non-pharmacological ways that can be given to the elderly is relaxation.

The results of this study are supported by previous study. Study conducted by Mau, et al., ${ }^{22}$ which revealed that there was a significant effect between the administration of Benson's relaxation therapy and insomnia in the elderly at the Operational Services Unit (Unit Pelayanan Teknis / UPT) of Budi Agung Kupang Social Home for Elderly. In addition, study by Safitri, et al., 23 also showed that there was a relationship between relaxation and improvement in sleep quality of elderly in Cakranegara Primary Health Care, West Nusa Tenggara Province.

The link between sex differences and sleep quality of the elderly is that there were 16 male elderly $(34.78 \%)$ and 30 female elderly $(65.21 \%)$ who had difficulty sleeping. The results of this study showed a higher percentage than the results of Webb's study, ${ }^{21}$ that one in five male elderly $(20 \%)$ and one in three female elderly $(30 \%)$ had difficulty sleeping. The value of sleep quality among female elderly was slightly higher than that of male seniors, namely 7.63 and 6.44, although the differences were not statistically significant and both were included in the "poor" sleep quality group. This finding is in line with study by Fatma on elderly people in Turkey. ${ }^{13}$ The value of sleep quality for female elderly in Turkey is 7.3 and the value for male elderly is 6.2. Both values also belong to the quality of "poor" sleep. Another study showed a different result with the present study in Ambon, especially relationship between sex and sleep quality. Alsulami, ${ }^{17}$ stated that there was a significant different between male and female in sleep quality ( $\mathrm{p}$-value = 0.032). It was caused by the difference of respondent. Alsulami's study, ${ }^{17}$ used the intensive care unit patients, while the present study in Ambon used female elderly in social institution.

The link between age and sleep quality of the elderly, is that older people ( $\geq 75$ years) had a higher quality of sleep than those in relatively younger age (60 -74 years), although the difference in values did not indicate statistical significance. This description is different from the results of the study on the elderly in Turkey. ${ }^{13}$ Fatma's study showed that the value of sleep quality for older people ( $\geq 75$ years) was actually lower than for younger people (60 - 74 years). ${ }^{13}$ This difference is likely due to differences in the characteristics of research subjects. The research subjects in Ambon were elderly living in the social institution, while the study subjects in Turkey were elderly living at home.

In relation to the disease suffered by the elderly, it is known that most of the elderly at the Tresna Werdha Inakaka Social Institution in Ambon, Maluku suffered from illness and only two elderly people $(4.34 \%)$ had no disease (see Table 1). The score of sleep quality of elderly with disease and disorder was in the range of $5.17-8.00$ scores or included in the group of "poor" sleep quality. Elderly people with ARI, hypertension and ear disorder had relatively high sleep quality values, which are respectively 8.00; 7.86 and 7.83 compared to elderly with other diseases. The difference in the value of sleep quality was not statistically significant and the values were classified as "bad" sleep quality. The description of the quality of sleep for elderly people with the disorder is in accordance with Amir, ${ }^{24}$ that elderly people with depression, stroke, heart disease, lung disease, diabetes, arthritis, or hypertension often report that quality sleep is poor and sleep duration is less if compared to healthy elderly. On the other side, the study by Gardiner P, et al., 10 stated that relaxation techniques can potentially reduce symptoms or outcomes in some following conditions, including high blood pressure and diabetes. This was caused by the difference of respondents. Gardiner P, et al., ${ }^{10}$ used medical office visitors while the present study used elderly social institution. Mitra $\mathrm{H}$, et al., 18 also stated that regular practice of the relaxation response not only alleviates stress and anxiety, but also directly affects physiologic factors, such as blood pressure, heart rate and oxygen consumption.

The limitation of this study is that the subject came 
from the inhabitants of the Tresna Werdha Inakaka Social Institution in Ambon City, Maluku Province, which were grouped according to the occupancy in the buildings at the social home (non-randomized). In addition, this study has a small sample size, therefore, it needs to be careful to generalize other populations.

\section{Conclusion}

Benson's relaxation therapy can significantly improve the quality of sleep for elderly in the Tresna Werdha Inakaka Social Institution in Ambon, Maluku, as indicated by the decrease in global PSQI Values. There is no significant difference between sex, age, types in elderly's sleep quality.

\section{Recommendation}

To managers of the Tresna Werdha Inakaka Social Institution Ambon, Benson's relaxation therapy can be applied the elderly with sleep disorder by paying more attention to those aged $\geq 75$ years and suffering from ARI, hypertension and rheumatism.

\begin{abstract}
Abbreviations
WHO: World Health Organization; Global PSQI: Global Pittsburg Sleep Quality Index; ARI: Acute Respiratory Infections; Intensive Care Unit (ICU); UPT: Unit Pelayanan Teknis / Operational Services Unit.
\end{abstract}

\section{Ethics Approval and Consent to Participate}

This study received Ethical approval from Health Research Ethics Commission of Surabaya Health Polytechnic of Ministry of Health, Number: 050/S/Kep/VI/2017, dated on June 13, 2017.

\section{Competing Interest}

Author declares that there are no significant competing financial, professional, or personal interests that might have affected the performance or presentation of the work described in this manuscript.

\section{Availability of Data and Materials}

Data collected without constraints.

\section{Authors' Contribution}

Nur Baharia Marasabessy, Lucky Herawati, and Irhamdi Achmad created the proposal. Nur Baharia Marasabessy and Irhamdi Achmad collected data in Tresna Werdha Inakaka Social Institution, Ambon, Maluku. Irhamdi Achmad analysed data and created the article.

\section{Acknowledgment}

The authors thank to Director of the Health Polytechnic Ministry of Health Ambon, Maluku for supporting this study.

\section{References}

1. Widyadharma. Perbedaan fungsi kognitif pada lansia yang kualitas tidurnya baik dan buruk. Neurona. 2012; 30 (1): 1-12.

2. Kyung Lee E, Douglass AB. Sleep in psychiatric disorder: where are we now?. The Canadian Journal of Psychiatry. 2010; 55 (7): 403-12.

3. Miller CB, Theorel-Haglow J, Barlett DJ, Yee BJ, Openshaw HD, Grunstein RR. Gender differences in obstractive sleep apnoe, insomnia and restless legs syndrome in adults-what do we know? a clinical update. Sleep Medicine Review. 2018; 38: 28-38.

4. Adib-Hajbaghery M, Mousavi SN. The effects of chamomile extract on sleep quality among elderly people: a clinical trial. Complement Theraphies in Medicine. 2017; 35: 109-14.

5. Zdanys KF, Steffens DC. Sleep disturbances in the elderly. Psychiatric Clinic of North America. 2015; 38 (4): 723-41.

6. Wang H, Zee P, Reid K, Chervin RD, Patwari PP, Wang B, et al. Genderspecific association of sleep duration with blood pressure in rural Chinese adults. Sleep Medicine. 2011; 12 (7): 693-9.

7. Yang B, Xu J, Xue Q, Wei T, Xu J, Ye C, et al. Non-pharmacological interventions for improving sleep quality in patients on dialysis: systematic review and meta-analysis. Sleep Medicine Review. 2015; 23: 68-82.

9. Massachusetts General Hospital. How relaxation response may help treat two gastrointestinal disorders. ScienceDaily. 5 May 2015.

10. Gardiner P, Sadikova E, Filippelli AC, Mitchell S, White LF, Saper R, et al. Stress management and relaxation techniques use among underserved inpatients in an inner city hospital. Complementary Therapies in Medicine. 2015; 23 (3): 405-12.

11. Creswell J. Research design pendekatan kualitatif, kuantitatif dan mixed. Yogyakarta: Pustaka Pelajar; 2016.

12. Rambod M, Pourali-Mohammadi N, Pasyar N, Rafii F, Sharif F. The effect of Benson's relaxation technique on quality of sleep of Iranian hemodialysis patient: a randomized trial. Complementary Therapies Medicine. 2013; 6 (21): 577-84.

13. Fatma OO, Tuncel D, Taş F, Demirci N, Ozer A, Karaaslan MF. Relationship between sleep quality and depression among elderly nursing home residents in Turkey. Sleep Breath. 2012; 16: 1059-67.

14. Dahlan M. Statistik untuk dan kesehatan kedokteran. 6th ed. Jakarta: Salemba Medika; 2016.

15. Sugiyono. Statistik untuk penelitian. Bandung: Alfabeta; 2012. p. 72.

16. Herawati L. Uji normalitas data kesehatan menggunakan SPSS. 1st ed. Kadarusno A, editor. Yogyakarta: Poltekkes Yogyakarta Press; 2016. p. 17.

17. Alsulami G, Rice AM, Kidd L. Prospective repeated assessment of selfreported sleep quality and sleep disruptive factors in the intensive care unit: acceptability of daily assessment of sleep quality. BMJ Open. 2019; 9(6).

18. Mitra H, Fatemeh R, Seyedeh M, Fatemeh M. The impact of Benson's relaxation technique on the quality of sleep in the elderly. Topics in Geriatric Rehabilitation. 2019; 35 (1): 88-94.

19. Prayitno A. Gangguan pola tidur pada kelompok usia lanjut dan penatalaksanaannya. Jurnal Kedokteran Trisakti. 2002; 21 (1): 23-30.

20. Sherwood L. Fisiologi manusia dari sel ke sistem. Edisi 8. Jakarta: EGC; 2014. p. 289-309.

21. Maas ML, Buckwalter KC, Hardy MD, Reimer TT, Titler MG, Specht J. Asuhan keperawatan gerontik diagnosis. Jakarta: Penerbit Buku Kedokteran ECG; 2011.

22. Mau A, Kiik SM, Ban S. Pengaruh penerapan teknik relaksasi Benson terhadap gangguan tidur (insomnia) pada lansia di UPT panti sosial penyantun lanjut usia Budi Agung Kupang. Jurnal Ilmiah Keperawatan. 
Kesmas: Jurnal Kesehatan Masyarakat Nasional (National Public Health Journal). 2020; 15 (2): 65-72

2012; 1 (1): 1-5.

23. Safitri RP, Rusiana HP, Idris B. Pengaruh relaksasi progresif dengan peningkatan kualitas tidur pada lansia Puskesmas Cakranegara. STIKES
YARSI Mataram. 2012.

24. Amir N. Gangguan tidur pada lanjut usia: diagnosis dan penatalaksanaan. Cermin Dunia Kedokteran. 2007; 34 (04/157): 196-206. 